\title{
Maduabuchi Dukor and the Legacies of Ontological Practices in African Thought System
}

\author{
Adebayo Aina \\ Department of Philosophy, Olabisi Onabanjo University, Ago-Iwoye, Nigeria \\ Email: bayo_kofo@yahoo.com
}

Received September 11 ${ }^{\text {th }}$, 2012; revised October $10^{\text {th }}$, 2012; accepted October $25^{\text {th }}, 2012$

\begin{abstract}
A challenge human existence is confronted in contemporary society is the justification of a coherent social order. Most of these justifications have been grounded, over time, on natural approach to the neglect of the African ontological practice. This natural reference fails to account for the ontological practice premised on African belief system which reconciles the natural and spiritual aspects of human existence. The study adopts the analytic approach in philosophy which evolves a clarification of the ontological concept within the African context. The African ontological practice hinges on Dukor's perspective which provides for a coherent interconnection among social structure, law and belief system towards the certitude and trust making for harmonious human well-being. Social order is enhanced by this African ontological practice and should, therefore, be incorporated into the public sphere.
\end{abstract}

Keywords: African Ontology; Analytic Approach; Dukor; Human Existence; Social Order

\section{Introduction}

The paper aims to discuss the legacies of African ontological practice through the contribution of Maduabuchi Dukor within the confine of Igbo thought system. Dukor is a professional African philosopher whose corpus of work is a formidable task that permeated logic, ethics, epistemology and metaphysics, with special focus on comparative discourse, with a view to promoting African scholarship in the public space. Little wonder that his justification of African ontological practice provokes a concern for a viable social justice in complementing the administrative structure bequest on Africans by the colonial system. However, it should be noted that Africa's cultures share certain core concepts, values and beliefs in common. The work is structured thus: A clarification of African ontological practice; Dukor on African ontological practice; and the implications of Dukor's African ontological practice to contemporary society.

\section{Clarification of Concept: African Ontological Practice}

Ontology means the study or concern about what kinds of things exist or what entities there are in the universe. An entity is an existing or real thing. The fact that something exists seems to imply its separateness from other existence or entities. So the ontological idea attempts to identify the ultimate cosmic principle by which things come into existence (Uduigwomen, 2002; p. 154). The nature of these entities revolves around the relationship between two planes of existence: the spiritual existence and the natural existence. According to the Yoruba, the spiritual is housed by supernatural forces including Olódùmarè (the Supreme Being), the Orìsà (divinities), the Ajogun (anti-gods or malevolent gods), the Àjé and the ancestors; while the natural world (İsàlú-Àye) is the domain of human beings, animals and plants (Abimbola, 2006: p. 52). It is pertinent to note that the relationship between these two realms is not exclusive in nature. Rather, the natural and spiritual planes of existence form the same continuum. Dukor corroborates that all entities have a spiritual cause which engenders the belief in the personification of nature in form of gods or spirits, and this he refers to as Theistic Panpsychism (Dukor, 2010: p. 24). By Theistic Panpsychism, he means that "the Supreme Being is the creator, and the smaller gods, who were created by the same Supreme Being intermingle with mankind as the guardian of public order, morality and justice” (Dukor, 2010: p. 24).

Hence, the African belief system regards the spiritual realm as essential to the welfare of man. As such, it is believed to provide the natural existence with a useful overarching system which assists human being to organise reality and impose sanctions to his life. This emanates through the people's religious beliefs. As a result of this, according to Sodipo (2004: p. 88), "its explanation must be given in terms of persons or entities that are like persons in significant respects. For it is explanation like this that can reveal the motives that lay behind particular happenings; they alone answer the emotional question why the thing happened here, now and to me in particular". Thus mishaps, based on observation and knowledge of natural processes without remedy, are consigned to punishment by the supernatural forces. It is to say that the spiritual realm serves as "a means of resolving some of the significant puzzles of the human conditions" (Gbadegesin, 1984: p. 182). The inhabitant of the spiritual realm is endowed with extra-ordinary powers which cannot be perceived by man. It becomes imperative for man to continue to curry their favours for security and knowledge purposes. This is well summarised by Sodipo (2004: p. 89) thus:

The lorry driver who ties a charm to his lorry-seat and a magical object under the lorry's windscreen is not denying or trying to frustrate any of the general laws by which the motor-vehicle operates. He knows, as well as any sci- 
entific man, that if the brakes fail while the vehicle is moving at high speed there could be a serious accident. $\mathrm{He}$ is aware too that if the accident is serious enough, some of the passengers could die. But the general laws cannot answer for him the question where and when the brakes will fail, whether they would fail when the lorry is travelling at high or low speed and, should that happen, who of the passenger will be fatally wounded. The scientific man will push the application of general laws as far as it can go; after that chance takes over. But not so in Yoruba traditional thought. Even if a general law says that only one person out of a hundred passengers in a lorry involved in an accident would be saved the Yoruba believe that the gods, not chance, decide who that lucky one shall be and it is certainly worth trying to make oneself the lucky one through a charm or through the necessary sacrifice to some god or gods.

From this viewpoint, the African attributes to Supreme Being through the gods those things for which they "cannot find naturalistic explanation” (Oladipo, 1992: p. 49). This belief is also found in Akan culture in Ghana. Kwasi Wiredu (1980: p. 19) gives an interesting illustration to show how people explain away some metaphysical issues, with the story of an imaginary traveller who dies in a bus crash, thus:

When he originally tried to get on the bus, the bus was already filled to capacity with passengers but just as he decided to postpone his journey and as he is turning to go, a seat is vacated. One passenger, for one reason or the other, has to get off in a hurry. So he gets on. His destination is the very first stop on the bus, and he is in fact, the passenger travelling the shortest distance. But just one mile from his destination the calamity occurs: a puncture and the bus crashed. Unbelievably, everyone on board escapes with minor bruises except one. Alone, of fifty passengers our traveller dies.

However, three points, among others, may be raised from Sodipo and Wiredu's narrations. First, the Yoruba will attribute the ill fatedness of our traveller, out of helplessness, to the wish of the spiritual realm, perhaps Olódùmarè's sanctions. This is reflected in sayings like bo se yan tì e nìyen (That is how he has chosen his portion from spiritual world) or ibi ti àyànmo e gbé é dé ni yèn (That is the extent of his chosen portion). Also, this may be the consequence of an inherited family curse. Sanctions of this nature might have been out of ill-treatment of fellow human beings in the time past. That is why the Yoruba say á $o$ be èsè baba wó lára omo (we shall revisit the father's punishment on the children). Besides the above instances, further justification of ontological practice may generate out of the practice of cursing through the aid of some gods. For example, a farmer may curse anyone who steals from his farm and by the invocation of the god's power inflict punishment on the thief. At other times, the victim of some robbery would go to a shrine and ask a god to sanction the culprit in a particular fashion and would promise rewards to the god. The culprit possessed by the god, perhaps by the Ayelala shrine, would make his way to the shrine and confess. Most often series of strange death may occur in the culprit's family (Adegbola, 1998: pp. 171-172). Hence, the belief in the deities only serves as a means of averting earthly havoc as well as a kind of comfort in the time of adversity. So prayers often said through a deity to Supreme
Being are, to borrow the words from the Akan tradition, meant mostly:

For material well-being and earthly blessings, such as riches, health, social peace and harmony, fertility, birth of many children, and continuity of life and vitality, and protection from evil, danger or death, petition for healing and longevity (Gyekye, 1996: p. 16).

It implies that the African is not particularly attracted to the union of human soul with Supreme Being in the spiritual realm but rather aspire for the promotion of human welfare and happiness through some mystical way of fulfilling these needs. So in the event where a god failed to "deliver on a request sought in prayer, that deity will be censured, treated with contempt, and ultimately abandoned by the people” (Gyekye, 1996: p. 16). In short, the spiritual realm serves as a referent point to the sustenance of the social solidarity, harmony and cooperation values. In addition to this social role, the spiritual realm sanctions moral obligations and responsibilities of the members of the community. These sanctions used to be very effective instruments for the enforcement of morality in society. We should note that it is not so much the physical hardship of going through the punishments that confine people to observe the moral codes but rather the threat of disgrace to one's family, and above all to one's offspring (Adegbola, 1998: p. 173). It is believed by the people that whenever misfortunes and disasters, as experienced by our traveller, occurs they most often interpret them as punishment sent by the Supreme Being for bad conduct or inability to act on some moral obligation to the community. Similarly, misfortunes suffered could then be the product of "unethical behaviour" which serves as lesson for thorough examination of moral behaviour in the community (Gyekye, 1996: p. 18). There is then the need to show that it is the responsibility of man, as a sensible being, to maintain the delicate balance between the two realms of existence. This manifests in Dukor's discussion of the humanistic orientation in African, perhaps Igbo, ontological practice.

\section{Dukor on African Ontological Practice}

Thus far, we are informed that the African appeal to the extra-human powers, in the spiritual realm, is merely with the motive of furthering the maintenance of social harmony in the natural realm of existence. Dukor (2010: p. 34) affirms this in the Igbo parlance that sometimes people were reported to have been pushed to the point of warning a particular god of injustice to the extent that some gods, goddesses, and spirits may not after all be the true manifestation of the Supreme Being. Bewaji (2004: p. 399) compliments that it is "mainly intended to lend legitimacy through an already available reinforcement mechanism to what is often taken for granted as morally obligatory”. Indeed, it is what assures the happiness and prosperity of individuals and community. But this harmonious cooperation in this belief system depends on humanistic basis of the people's moral value.

Hence, we may tarry a while to discuss the meaning of moral value in order to boost the understanding of the humanistic orientation. According to Kwame Gyekye (1996: p. 55), moral value involves:

A set of social rules and norms intended to guide the conduct of people in a society. The rules and norms emerge 
from ... people's beliefs about right and wrong conduct and good and bad character. Morality is intrinsically social, arising out of the relations between individuals; if there were no such a thing as human society, there would be no such thing as morality. And, because morality is essentially a social phenomenon ... consideration for the interests of other and, hence a sense of duty to others are intrinsic to the meaning and practice of morality.

This viewpoint on moral values draws attention to two implications. First, it attempts to affirm that moral discourse is primarily a "this-worldly" affair in which one focuses on issues of cooperation, actions, attitudes, emotion, public order and character, Secondly, it espouses social morality wherein humanistic practice is grounded. This represents an ascending order from the austerely commitment to social sympathies of rigorous individualism to the pervasive commitment to social involvement. Now, on "this worldly" conception of moral value in Igbo thought system, man is equated to maintain an interactive course of duty where love, patronage, recognition, compassion, companionship are not only generated but also equitably distributed in the community. Most of these precepts show "that members of the community are endowed with reason and intention to show responsibility in preserving the sacrosanct of moral values and ethos of the society” (Dukor, 2010: p. 17) Thus the harmonization of these interests account for what is good. The absence of this ethic of responsibility in man's behaviour is an act of injustice in African parlance. And this may provoke in Igbo belief system the infractions against man qua man, as well as the spiritual beings. It involves the descending from "communal covenantal grace into isolated individualism" (Amponsah, 1974: p. 71). Dukor (2010: p. 18) adds that these values include,

One shall not kill or steal. Killing or taking of another's life is an abomination and contrary to the will of the goddess, Ani and the Almighty, Chukwu. Nemesis of death or madness normally trail after any person who commits murder ... Stealing of any sort which is an infringement on someone else's right and contrary to the spirit of communalism is seriously frowned by the society ... Stealing in the society attracted the wrath of the god or goddess or outright banishment.

In this respect, its consequence brings the calamities not only on the culprit(s) but on the family and the community in general, and these are often seen as punishment. That is why the Igbo critically frown at unruly behaviour as its disgrace terminates not at the recalcitrant. Thus the proverb "when a man dances badly in public, it is his brothers that get the itching brow" (Dukor, 2010: p. 17).

Nevertheless, the second implication of the moral values in African culture strongly recommends the principle of social practice. By this we mean social reverberations of an individual's conduct of good character in the community. It is due to the fact that a human being is part of a social whole. This social practice, that an individual does not and cannot exist alone except corporately, is illustrated by Segun Gbadegesin (1991: pp. 61-62) thus:

The new baby arrives into the waiting hands of the elders of the household. Experienced elderly wives in the household serve as mid-wives, they see that the new baby is de- livered safely and the mother is in no danger after delivery. They introduce the baby into the family with cheerfulness, joy and prayer: "Ayo abara tintin" [This is a little thing of joy]. From then on, the new mother may not touch the child except for breast feeding. The baby is safe in the hands of others: Co-wives, husband's mother and stepmothers and a whole lot of others, including senior sisters, nieces and cousins. On the seventh or eight day, the baby gets his/her names, a ceremony performed by the adult members of the household ... The meaning of this is that child, as an extension of the family tree, should be given a name that reflects his/her membership therein, and it is expected that the name so given will guide and control the child by being a constant reminder for him/her of his/her membership in the family and the circumstance of his/her birth.

The above excerpt implies that an individual cannot run adrift from the community that nurtures him/her. Rather the individual, through socialization and the love and concern which the community extended to him/her, cannot now see him/herself as an isolated being. This social character is intrinsic to the notion of morality in Igbo culture. This is grounded in human experiences in living together. Even the Republican nature of the Igbo culture recognises with strong emphasis on the respect and promotion of individual rights to the communal institutions and properties but with some limitations, which are theoretical and practical in nature (Dukor, 2010: pp. 19-20). The Igbo do not hesitate to say, in compliment of communitarianism, thus: Egbe belu ugo belu, Nke si-ibeya-ebena, nku kaa-ya (Kite perches and eagle also perches; if any one says the other will not perch on the tree, her feather will be broken). It implies that wisdom is not limited to a given class of people in traditional Igbo society. Rather, it recognises the contribution of every rational being, old and young, towards the betterment of the whole community. The point here is that every person should have a chance to contribute to the development of the society. This implies that no point of view should be suppressed in the process of deliberation and no arbitrary exercise or power should be allowed. The importance of cross fertilization of ideas in decision making is germane in this society. Hence, man owes his existence to other people, including those of past generations and his contemporaries. Whatever happens to the individual is believed to happen to the whole group, and whatever happens to the whole group is the responsibility of the individuals. Thus the brotherhood concept: onye aghana nwannie.

It shows that in realising this objective of communalism, "every ... child is given moral instruction during the process of socialisation to inculcate a sense of community" (Gyekye, 1987: p. 46). Hence the saying by John Mbiti, "I am because we are, and since we are, therefore I am” (Mbiti, 1982: p. 106). But this Mbiti's epithet is wrongly interpreted by Nyasani to merely be the frustration of individual's creativity and ability to innovate, by the communal dictatorship as "relatively unilinear, uncritical, lacking in initiative and therefore 'encapsulated"” (Lassiter, 1999). He further adds that,

[W] hat we experience in the practical life of an African is the apparent stagnation or stalement in his social as well as economic evolution ... It is quite evident that the social consequences of this unfortunate social impasse (encap- 
sulation) can be very grave especially where the process of acculturation and indeterminate enculturation is taking place at an uncontrollable pace ... By and large, it can safely be affirmed that social encapsulation in Africa works both positively and negatively. It is positive in as far as it guarantees a modicum of social cohesion, social harmony and social mutual concern. However, in as far as it does not promote fully the exercise of personal initiative and incentive, it can be regarded as negative (Lassiter, 1999).

Nyasani missed the point here. "Personal initiative and incentives" are encouraged in this thought system. This will unfold in the course of analysis. An Igbo man has an obligation to maintain harmonious relationship among all the members of the community and to do what is necessary to correct every breach of harmony and to strengthen the community bonds, especially through the principle of justice. Dukor explicates further with his allusion to the unadulterated pre-colonial conception of justice which is similar in content to the social contractarians: John Locke and J. J. Rousseau's ideas. Dukor depicts the Igbo justice system to the state of nature where peace, goodwill, mutual assistance and preservation of lives reign supreme in contrast to the Hobbesian principles (2010: pp. 21-22). Hence, Justice, in this thought system, hinges on the combination of moral law, divine law and natural law; and what is moral cannot be illegal and what is illegal cannot be immoral because that which is bad from the beginning does not improve by length of time (Dukor, 2010: p. 24). What Dukor attempts to emphasise here is the necessary and sufficient connection between law and morality which is rooted in the ontological belief system discussed in the last section. Justice strongly holds where the instruction of the spiritual realm is abided by and grounded on the moral belief. As a result, any adjudication that does not toll this line will be met with calamitous consequences in the community. This shows that justice involves some aspects of punishment.

Punishment in this tradition helps in maintaining social order. It further performs a tripartite role in African, perhaps Igbo thought system: deterrent, reforming and restitution. Dispensation of justice is not a hereafter concept but rather offence(s) are dealt with in the natural plane of existence. Dukor (2010: pp. 27-28) explicates that

Misfortune may be interpreted as indicating that the sufferer has broken some moral or ritual conduct against God, the spirits, the elders or other members of his society. However, in some cases appeasement or atonement can be made in form of restitution and punishment for various offences. It could be death for offences like practising sorcery and witchcraft, committing murder and adultery and it could be payment of fines in cash or kind for other minor offences. The elders deal with disputes and breaches arising from various types of moral offences against custom and ritual.

This shows that there cannot be any hiding place for criminal offenders in Igbo society with the proactive course for social justice. It also enlightens the society on the need to inculcate morally commendable conducts expected in the context of a social morality (Gyekye, 1987: p. 67). In short, it shows punishment in this context as not limited to the relationship between natural beings qua natural beings but also encompassed that of spiritual being. Here, greater value is attached to the feeling of communal fair play and justice, with the motivational belief that an individual must exercise restraint and take responsibility for his/her actions. If otherwise, the efficacy of the moral sanction and punishment ensued. Hence the community need to offer sacrifice to these supernatural forces in order to survive. They also need to appease the benevolent forces so as to continue to enjoy their support and blessings. More so, they need to reparate the malevolent forces so that they might not oppose them whenever an important endeavour is embarked upon. For example, the spiritual realm hates any act of violence and injustice, any instance of breaking the social order and violating specific bans. All these attract to the natural realm punishment with shortage of agricultural produces, famine, infertility, drought or illness. These beliefs are premised on the fact that there is a continuum between the spiritual and natural realms of existence. Also, that life goes on beyond the grave for the Igbo and is a continuous action and interaction with the ancestors. This reflects that culprits will not only be sanctioned but commensurability is also assured towards appropriate justice (Dukor, 2010: pp. 30-34).

By and large, the communalistic orientation of Igbo society emphasizes the notion that an individual's image will depend rather crucially upon the extent to which his or her actions benefits him/herself first but yet satisfy the interest of others which is not, of course, by accident or coincidence but by design. It is important for man to see to his ambitions, desires, and actions but not at the detriment of needs and interest of others. In another sense, human conduct in Igbo culture demands absolute behaviours grounded in personal and social well-being.

\section{The Implications of Dukor's African Ontological Practice to Contemporary Society}

The primary implication to the ontological practice hinges on the questioning of its background in-itself. The practice is beclouded by the social morality as expressed in the Igbo culture which is in part codified in the traditional African laws, and whose condemnation of crime punishment in justice system is taken to express. Fundamentally, one might raise doubt as to its soundness, its homogeneity, and the consistency and authenticity of the judgement it passes on crime through punishment. Its response to the challenges of public order is cloudy going by its ordeal and oath taking approaches to social justice system. One may say that it instils anticipated fear of attempting crimes in the first place rather than engaging in the dispensation of justice.

Besides, this African ontological practice might be taken to believe uncritically that the social morality of society is selfauthenticating that its principles are moral axioms and that social justice is conclusively justified once it is shown to express the emphatic moral condemnation of actions offending against the ontological practise whereby the supernatural realm provides the natural realm with a useful overarching system which assist human being to organise reality and impose sanctions to his life. But, to what extent can this go even where morality itself is morally flawed?

Also, an eagle-eyed view of the Ontological practice in Igbo culture might be thought to assuming that social morality is a much more homogeneous set of beliefs and attitudes than the reality of most contemporary societies would warrant. It is pertinent to note that contemporary society is as typically plural- 
istic and conflict-ridden in the area of morals as in other fields of study. It is factual that there can never be a moral consensus among all human beings. It is indeed true that the reality on the ground is the lack of moral consensus. People vary greatly in the way they view issues. Some have no moral opinions of their own but accept the opinion which has been laid down by their custom or traditions. Some have highly developed moral convictions and a strong sense of right and wrong. Some adjust this sense of right and wrong depending on the circumstances and whether it suits them. Therefore, what we now have today is almost as many moral opinions as there are human beings. However, there are still a great number of people who have common ground on a number of issues but as can be seen these mostly contain nothing fundamental and everything can still in most cases be interpreted in ways that will suit the individual or even probably evade the issue altogether. To this end, on many moral issues, one may likely find not one acceptable stand but two or more different and even mutually opposed views, supported by significant sections of society. The dilemma then is which of them is to be expressed on the view of social justice grounded on ontological practice and in law for offending against it?

These, at the end, raise dust as to the consistency and authenticity of the condemnation conveyed through social justice. Ontological practice may breed double standards where in some instances questions of shame and hypocrisy can rise and one might suspect that punishment is not much more than a "fetishistic surrogate" for a value which is not given expression in other area of life (Primoratz, 1989: p. 204).

However, the responses to these anticipated implications of soundness, homogeneity, and consistency and authenticity of punitive measures levied against African ontological practice may after all not assume to damaging its construction but rather to point out the conditions of its proper applications. It should be noted that the part of the Igbo social morality, which co-extend with its social justice, are basically sound. Hence the traditional Igbo social morality flourishes from time immemorial and its strengths learn credence to its accessibility and dynamism which motivate cultural experiences. After all if one cannot accept the moral outlook of a society, it is imperative that we withhold support when it expresses moral condemnation through punitive measures. African ontological practice is rooted in this justification.

The justice system, in this tradition, functions not so much to reform or deter potential offenders, but rather to maintain social cohesion by safeguarding a vigorous collective conscience. Implicitly, this ontological system offers an account of practice which ascertains a measure of moral consensus despite the anticipated criticisms. It justifies those actions that are based on this consensus and, at the same time, refuse justification to those that transcend it. In fact, social morality is the bases on which the contemporary society is grounded. Thus society legitimately expresses moral condemnation by punishment only when its conscience speaks strongly and unequivocally with one voice. Hence, sincerity is necessary in this punitive approach to sanction rather than furthering conditions that promote double standard in punishment. Hence, the system of ontological practice does not hesitate to blame and punish alike offenders adjudged to contravene her value system. They believe in a continuity of life and a community of interest between the two realms of existence. Conflicts to them are a part of life which must not be allowed to be resolved by individual parties in order not to disrupt the social order. A strong sense of sanction is meted to the individual who acts or contravenes the common good of the community and its values despite the protection of individual interests.

\section{Conclusion}

The study has shown that the African lived experiences are rooted in her ontological practice. And its further discourse by Maduabuchi Dukor provokes a systematic display of social justice whereby the wrong and the wronged are appropriated deserted in order to maintain and promote harmony between the two planes of human existence. This engenders the belief in a continuity of life and a community of interest where objective truth in place of deception, to the extent that the ordeal and oath taking mechanism are upheld to instil in people conscientious attitude in the system. Besides, the study is after all man's response to meet the challenges of his time. Thus, a more critical study of the past is brought to the fore, in the present, in order to make room for strong social justice for the best future of contemporary society. In addition, the punitive measures grounded in this social morality are not treated at prima-facie level, but rather transcend the immediate offenders on to the family and community where the offender is necessarily a member. Implicit here is the idea of reconciliation whereby the offender is restitutively reconcile to himself, the victim concerned in the case and the entire community at large.

By and large, the discussion of ontological practice is of importance in African thought system due to the crucial role it will serve in determining the direction of contemporary political, socio-cultural and economic system.

\section{REFERENCES}

Abimbola, K. (2006). Yoruba culture: A philosophical account. Birmingham: Iroko Academic Publishers.

Adegbola, A. E. A. (1998). Traditional religion in West Africa. Ibadan: Sefer.

Amponsah, K. (1974). Topics on West African traditional religion I. Accra: McGraw-Hill FEP.

Bewaji, J. A. I. (2004). Ethics and morality in Yoruba culture. In K. Wiredu (Ed.), A companion to African philosophy. UK: Blackwell Publishing.

Dukor, M. (2010). African philosophy in the global village: Theistic panpsychic rationality, axiology and science. Germany: Lap Lambert Academic Publishing Gmbh \& Co.

Gbadegesin, S. (1984). Destiny and the ultimate reality of human existence: A Yoruba perspective. Ultimate Reality and Meanings: An Interdisciplinary studies in the Philosophy of Understanding, 7, 173188.

Gbadegesin, S. (1991). African philosophy: Traditional Yoruba philosophy and contemporary African realities. New York: Peter Lang.

Gyekye, K. (1987). An essay on African philosophical thought: The African conceptual scheme 1. Cambridge: Cambridge University Press.

Gyekye, K. (1996). African cultural values: An introduction. Accra: Sankofa Publishing Co.

Lassiter, J. E. (1999). African culture and personality: Bad social science, effective social activism, or a call to reinvent ethnology? http://web.africa.Ufl.edu/asq/v3/v3i2a1.htm

Mbiti, J. (1982). African religions and philosophy. London: Heinemann.

Oladipo, O. (1992). The idea of African philosophy. Ibadan: Molecular Press.

Primoratz, I. (1989). Punishment as language. Philosophy, 64, 248. doi:10.1017/S0031819100044478

Sodipo, O. (2004). Notes on the concept of cause and chance in Yoruba traditional thought. In A. Fadahunsi, \& O. Oladipo (Eds.), Philosophy 


\section{A. AINA}

and the African prospect: Selected essays of Professor J. Olubi Sodipo on philosophy, culture and society. Ibadan: Hope Publications. Uduigwomen, A. F. (2002). Footmarks on African philosophy. Somolu:
Obaroh and Ogbinaka Publishers Ltd.

Wiredu, K. (1980). Philosophy and an African culture. Cambridge: Cambridge University Press. 